\title{
Correction to: Comparative in vitro seed germination and seedling development in tropical and temperate epiphytic and temperate terrestrial orchids
}

\author{
Surya Diantina ${ }^{1,2}$ (D) . Suskandari Kartikaningrum ${ }^{2} \cdot$ Andrea Clavijo McCormick $^{1}$ (D) James Millner ${ }^{1} \cdot$ Craig McGill $^{1}$ D . \\ Hugh W. Pritchard ${ }^{3}$ D . Jayanthi Nadarajan ${ }^{4}$ (D)
}

Published online: 28 December 2020

(c) Springer Nature B.V. 2020

\section{Correction to: Plant Cell, Tissue and Organ Culture (РСТОC) (2020) 143:619-633 \\ https://doi.org/10.1007/s11240-020-01947-7}

Several references in the initial online publication were incorrect. The original article has been corrected.

Publisher's Note Springer Nature remains neutral with regard to jurisdictional claims in published maps and institutional affiliations.

The original article can be found online at https://doi.org/10.1007/ s11240-020-01947-7.

Surya Diantina

suryadiantina@pertanian.go.id

$\triangle$ Jayanthi Nadarajan

jayanthi.nadarajan@plantandfood.co.nz

1 School of Agriculture and Environment, Massey University, Tennent Drive, 4410 Palmerston North, New Zealand

2 Indonesia Agency for Agricultural Research and Development (IAARD), Jl. Ragunan 29, Pasar Minggu, 12540 Jakarta Selatan, Indonesia

3 Royal Botanic Gardens, Kew, Wellcome Trust Millennium Building, Wakehurst, Ardingly RH17 6TN, West Sussex, UK

4 The New Zealand Institute for Plant and Food Research Limited, Batchelar Road, 4474 Palmerston North, New Zealand 